\title{
Some New Records and Status of Genus Steccherinum (Polyporales, Basidiomycota) in India
}

\author{
Sanjeev Kumar Sanyal, Ritu Devi, and Gurpaul Singh Dhingra \\ Department of Botany, Punjabi University, Patiala 147002, India \\ Correspondence should be addressed to Ritu Devi; sharma.ritu626@gmail.com
}

Received 29 August 2015; Revised 29 November 2015; Accepted 30 November 2015

Academic Editor: Laura Selbmann

Copyright (c) 2016 Sanjeev Kumar Sanyal et al. This is an open access article distributed under the Creative Commons Attribution License, which permits unrestricted use, distribution, and reproduction in any medium, provided the original work is properly cited.

Information on ten species of genus Steccherinum in India is provided. Of these nine are based on the collections made from state of Uttarakhand during 2010-2012, whereas S. laeticolor has been described by earlier workers but could not be collected during the present study. S. albofibrillosum, S. bourdotii, S. ciliolatum, S. cremeoalbum, S. oreophilum, S. robustius, and S. subcrinale are new records for the state of Uttarakhand and described in detail; however for S. fimbriatum, S. laeticolor, and S. ochraceum annotated notes have been given. S. albofibrillosum, S. bourdotii, S. cremeoalbum, S. oreophilum, and S. robustius are being reported for the first time from India.

\section{Introduction}

Genus Steccherinum Gray belongs to family Phanerochaetaceae of order Polyporales in class Agaricomycetes (Phylum Basidiomycota, subphylum Agaricomycotina). It is a worldwide distributed genus with 73 known species (http://www .mycobank.org/, 2015). The genus is characterized by being resupinate, effused, reflexed to subpileate or pileate, and odontoid to hydnoid basidiocarps, usually cream coloured with pinkish, orange hymenial surface having violaceous or brown tints, fibrillose margins, usually dimitic hyphal system (monomitic in Steccherinum albofibrillosum), encrusted skeletocystidia and ellipsoid to ovoid to subglobose, smooth, acyanophilous, and inamyloid basidiospores. According to Binder et al. [1, 2], genus Steccherinum does not show any clear cut monophyletic lineage but belongs to "residual polyporoid clade," a heterogeneous group of Polyporales that did not belong to any of the recognized lineages (Antrodia, core polyporoid, and phlebioid clades) defined by them. Earlier workers Thind and Khara [3]; Rattan [4]; Lalji [5]; Bhosle et al. [6]; Ranadive et al. [7]; Sharma [8]; Prasher and Ashok [9]; Prasher and Lalita [10]; Ranadive [11]; Dhingra et al. [12] have described/listed 5 species, namely, $\boldsymbol{S}$. ochraceum, S. ciliolatum, S. fimbriatum, S. laeticolor, and S. subcrinale from different localities of India, of which $S$. ochraceum, S. fimbriatum, and S. laeticolor are known to be from Uttarakhand. Here we account 10 species, of which $S$. albofibrillosum, S. bourdotii, S. ciliolatum, S. cremeoalbum, $S$. oreophilum, S. robustius, and S. subcrinale are being reported for the first time from Uttarakhand with S. albofibrillosum, S. bourdotii, S. cremeoalbum, S. oreophilum, and S. robustius being new records from India. A key to all the 10 species has also been given in Table 1 .

\section{Materials and Methods}

Material has been collected from various localities of Uttarakhand during fungal forays conducted from 2010 to 2012. Microscopic details related to hyphae, cystidia, basidia, and basidiospores of the specimens were studied by making crush mounts and hand cut sections in water, $3-5 \% \mathrm{KOH}$ solutions, and stained in $1 \%$ Congo red, $1 \%$ Phloxine, $1 \%$ Cotton Blue in Lacto-phenol, Melzer's Reagent, and Sulphovanillin. Line diagrams were made using camera lucida in combination with compound microscope at different magnifications and were compared with the published literature. Interesting specimens were sent to Professor Nils Hallenberg (Sweden) for expert opinion and comparison. Colour standards used are as per Methuen's Handbook of colors by Kornerup and Wanscher [13]. Specimens pertaining to these species have 
TABLE 1: Key to the species.

1. Hyphal system monomitic

1. Hyphal system dimitic

2. Hyphae without clamps

2. Hyphae with clamps

3. Basidiospores longer than $5 \mu \mathrm{m}$

3. Basidiospores smaller than $5 \mu \mathrm{m}$

4. Basidiocarps violaceous, with fimbriate to rhizomorphic margins

4. Not as above

5. Hymenophore aculei with rounded tips

5. Hymenophore aculei with conical tips

6. Basidiospores narrowly ellipsoid

6. Basidiospores ellipsoid, broadly ellipsoid to subglobose

7. Basidiocarps pinkish brown to orange red; aculei up to $2.5 \mathrm{~mm}$ long

7. Basidiocarps orange white to pale orange to grayish orange to brownish orange; aculei up to $1.5 \mathrm{~mm}$ long

8. Basidiocarps pale orange to grayish orange, but not brownish, aculei up to $0.5 \mathrm{~mm}$ long; basidiospores ellipsoid

8. Basidiocarps orange white to grayish orange to brownish orange, aculei up to $1.5 \mathrm{~mm}$ long, basidiospores ellipsoid to broadly ellipsoid to subglobose

9. Basidiospores ellipsoid

9. Basidiospores broadly ellipsoid to subglobose
S. albofibrillosum

2

S. creameoalbum

3

S. oreophillum

4

S. fimbriatum

5

S. ochraceum

6

S. subcrinale

7

S. laeticolor

8

S. ciliolatum

9

S. robustius

S. bourdotii been deposited in the Herbarium, Department of Botany, Punjabi University, Patiala, India (PUN). Nomenclature follows Blackwell et al. [14]; James et al. [15]; Hibbett et al. [16]; Kirk et al. [17]; Bernicchia and Gorjón [18]; and http://www .mycobank.org/ (2015) as far as possible.

\section{Taxonomy}

3.1. Steccherinum albofibrillosum. Steccherinum albofibrillosum (Hjortstam \& Ryvarden) Hallenb. \& Hjortstam, Mycotaxon 31 (2): 443, 1988. Phlebia albofibrillosa Hjortstam \& Ryvarden, Mycotaxon 20 (1): 139, 1984 (Figures 1(1), 1(2), and 2(15-18)).

Basidiocarp resupinate, effused, adnate, up to $210 \mu \mathrm{m}$ thick in section; hymenial surface odontoid, yellowish white to pale orange to grayish orange when fresh, not changing much upon drying; margins thinning, fibrillose to indeterminate, paler or concolorous. Hyphal system monomitic. Generative hyphae, branched, clamped, thin-to thick-walled; basal hyphae up to $6.8 \mu \mathrm{m}$ wide, parallel to substrate, loosely interwoven; subhymenial hyphae up to $4.8 \mu \mathrm{m}$ wide, vertically arranged, compact. Skeletocystidia 73-113 × 9.4$10.6 \mu \mathrm{m}$, subcylindrical to subfusiform, thick-walled, heavily encrusted; projecting up to $43.0 \mu \mathrm{m}$ out of the hymenium. Basidia 18.8-25 × 5-5.6 $\mu \mathrm{m}$, clavate, 4-sterigmate, with basal clamp; sterigmata up to $2.6 \mu \mathrm{m}$ long. Basidiospores 3.4$5 \times 2.4-3.6 \mu \mathrm{m}$, ovoid to subglobose, smooth, thin-walled, acyanophilous, inamyloid.

Specimen Examined. India, Uttarakhand: Pithoragarh, Chaukori, on stump of Aesculus indica, Sanyal 6903 (PUN), September 06, 2011.
Remarks. S. albofibrillosum is characterized by grayish white to orange white, fibrous basidiocarps, and subglobose basidiospores. It was first described by Hjortstam and Ryvarden [19] as Phlebia albofibrillosa. Hallenberg and Hjortstam [20] shifted it to genus Steccherinum. Earlier, it was reported from Costa Rica and Nepal (http://www.mycobank.org/, 2015). Here, it is being described for the first time from India.

3.2. Steccherinum bourdotii. Steccherinum bourdotii Saliba \& A. David, Cryptogamie Mycologie 9 (2): 100, 1988 (Figures $1(3), 1(4)$, and 2(19-23)).

Basidiocarp resupinate, effused, adnate, up to $250 \mu \mathrm{m}$ thick in section; hymenial surface odontoid, aculei up to $1.5 \mathrm{~mm}$ long, pale orange to orange red when fresh, brownish orange upon drying; margins whitish, thinning, fibrillose to indeterminate, paler to concolorous. Hyphal system dimitic. Generative hyphae up to $3 \mu \mathrm{m}$ wide, branched, clamped, thinwalled; basal hyphae parallel to substrate, loosely interwoven; subhymenial hyphae densely packed, vertically arranged. Skeletal hyphae up to $4.4 \mu \mathrm{m}$ wide, generally unbranched, thick-walled, without septa and clamps. Skeletocystidia 98-112 $\times 6.8-8 \mu \mathrm{m}$, subcylindrical to subfusiform, richly encrusted, thick-walled; projecting up to $49 \mu \mathrm{m}$ beyond the hymenium. Basidia $18-20 \times 4.4-5.6 \mu \mathrm{m}$, clavate to subclavate, 4 -sterigmate, with basal clamp; sterigmata up to $3.4 \mu \mathrm{m}$ long. Basidiospores 3.0-4.4 $\times 3-3.8 \mu \mathrm{m}$, subglobose, smooth, thinwalled, guttulate, acyanophilous, inamyloid.

Specimen Examined. India, Uttarakhand: Dehradun, Chakrata, on stick of Cupressus torulosa, Sanyal 6904 (PUN), September 17, 2012. 


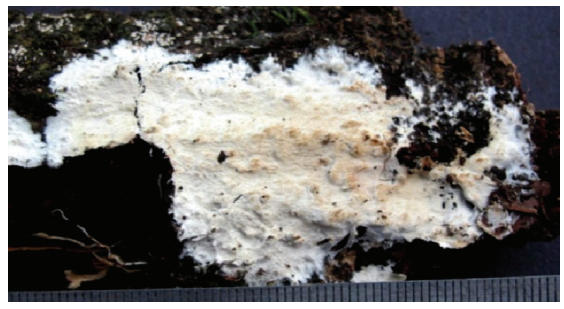

(1)

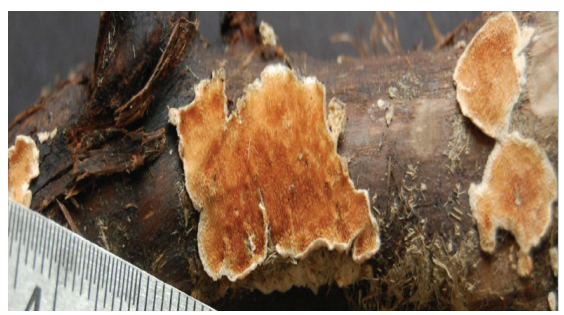

(3)

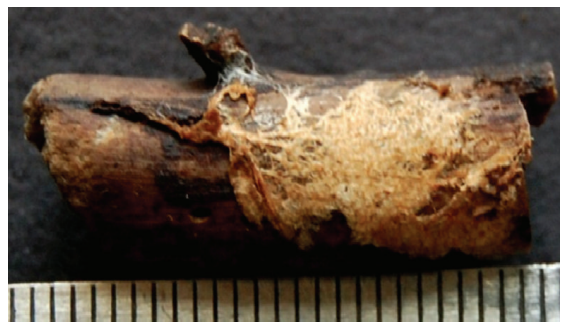

(5)

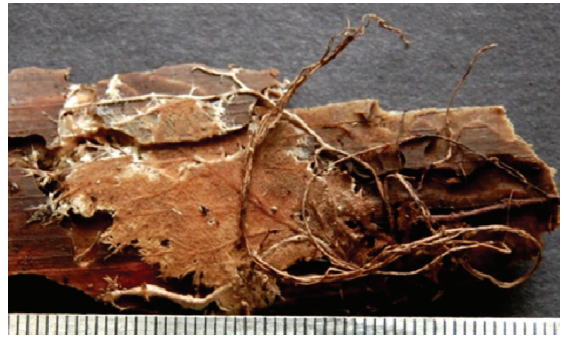

(7)

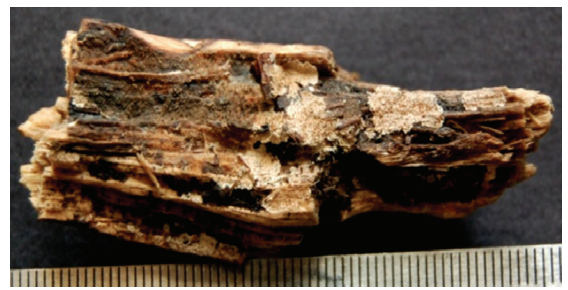

(9)

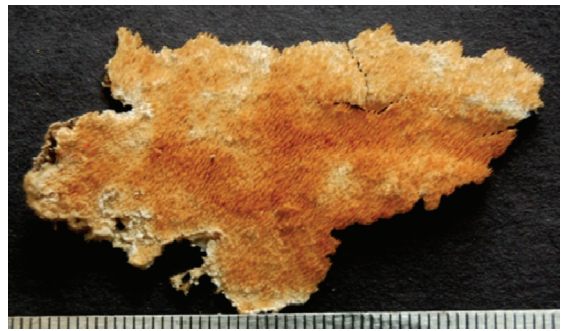

(11)

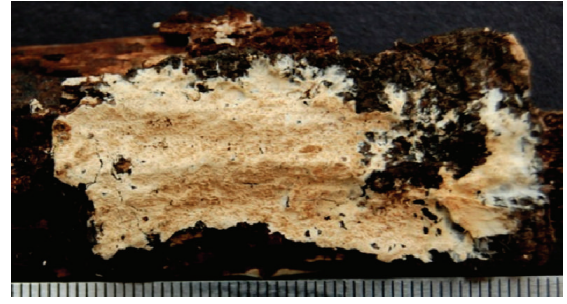

(2)

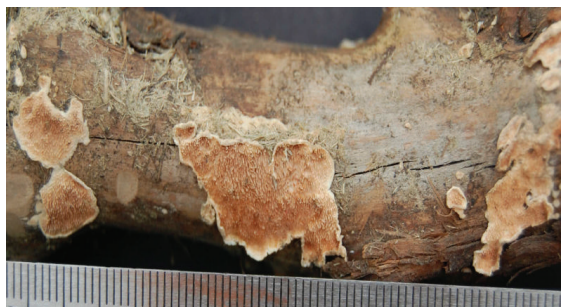

(4)

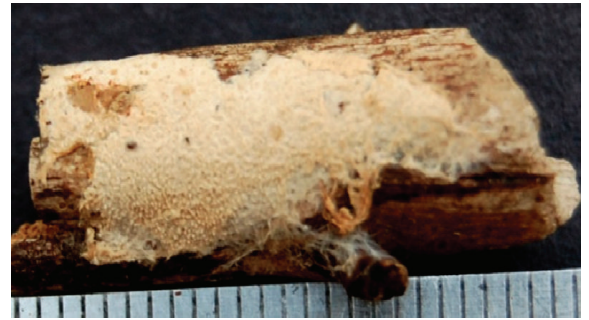

(6)

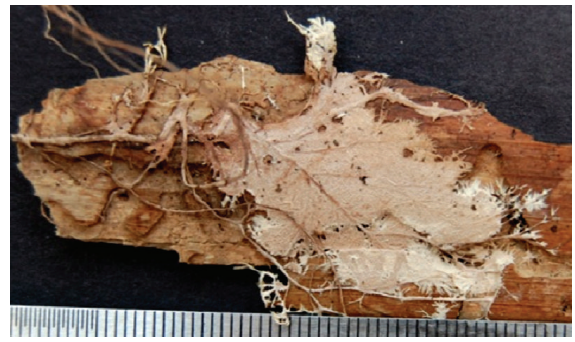

(8)

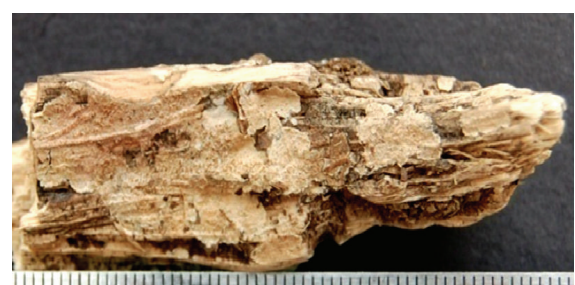

(10)

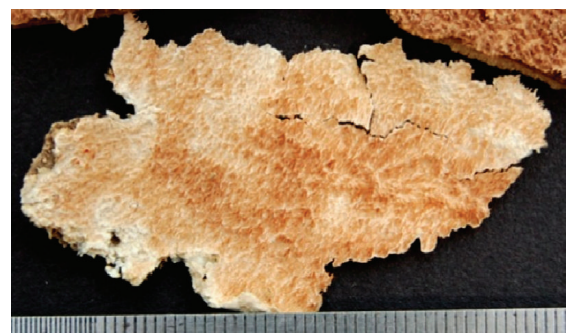

(12)

FIgURE 1: Continued. 


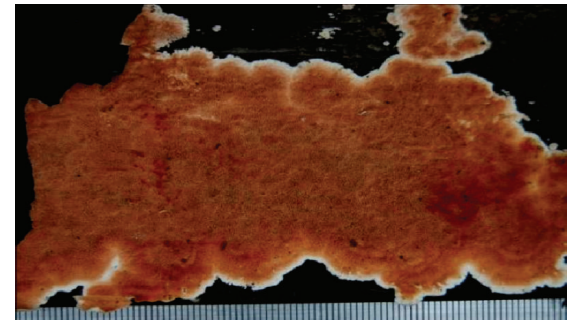

(13)

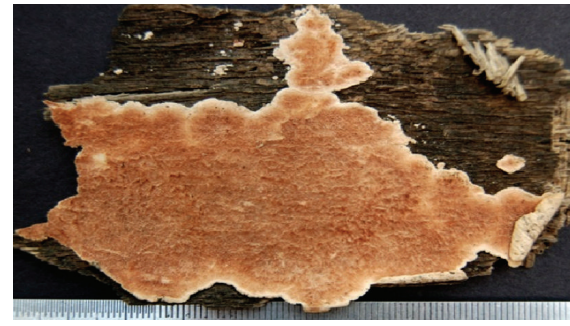

$(14)$

FIGURE 1: Basidiocarps of Steccherinum spp.: (1)-(2) Steccherinum albofibrillosum ((1) fresh, (2) dry). (3)-(4) Steccherinum bourdotii ((3) fresh, (4) dry). (5)-(6) Steccherinum cremeoalbum ((5) fresh, (6) dry). (7)-(8) Steccherinum fimbriatum ((7) fresh, (8) dry). (9)-(10) Steccherinum oreophilum ((9) fresh, (10) dry). (11)-(12) Steccherinum robustius ((11) fresh, (12) dry). (13)-(14) Steccherinum subcrinale ((13) fresh, (14) dry).
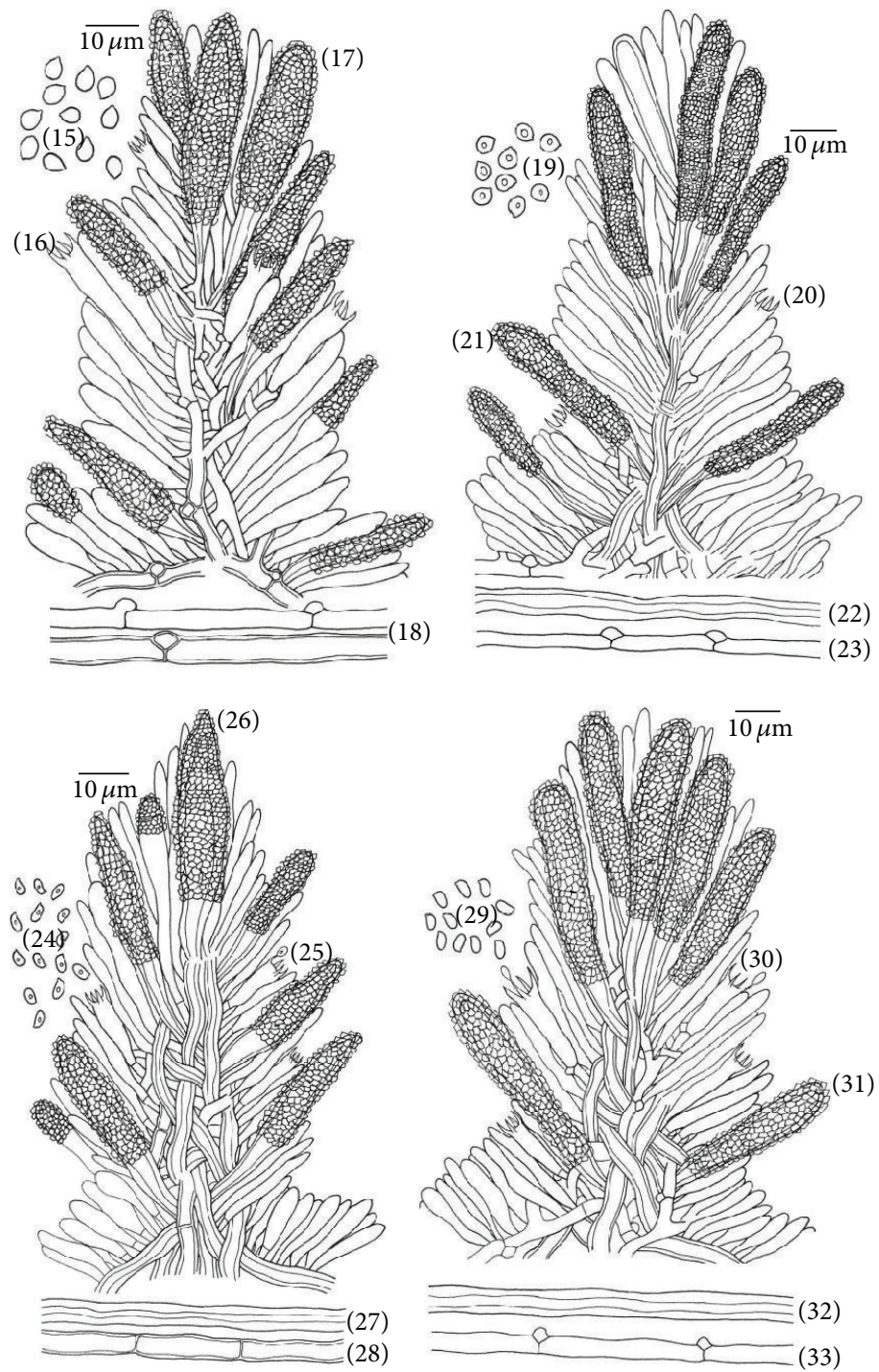

FIGURE 2: Microscopic features of Steccherinum spp.: (15)-(18) Steccherinum albofibrillosum ((15) basidiospores, (16) basidia, (17) cystidia, and (18) generative hyphae). (19)-(23) Steccherinum bourdotii ((19) basidiospores, (20) basidia, (21) cystidia, (22) skeletal hyphae, and (23) generative hyphae). (24)-(28) Steccherinum cremeoalbum ((24) basidiospores, (25) basidia, (26) cystidia, (27) skeletal hyphae, and (28) generative hyphae). (29)-(33) Steccherinum fimbriatum ((29) basidiospores, (30) basidia, (31) cystidia, (32) skeletal hyphae, and (33) generative hyphae). 
Remarks. This species is characterized by being subcylindrical to subfusiform, richly encrusted skeletocystidia, and subglobose basidiospores. It is distributed in the Caucasus, Belgium, Estonia, Finland, Germany, Italy, Macedonia, Poland, Russia, Switzerland, Turkey, Ukraine, and the United Kingdom (http://www.mycobank.org/, 2015) and is here described as a new record for India.

3.3. Steccherinum ciliolatum. Steccherinum ciliolatum (Berk. \& M. A. Curtis) Gilb. \& Budington, Journal of the Arizona Academy of Sciences 6: 97, 1970. Hydnum ciliolatum Berk. \& M. A. Curtis, Hooker's Journal of Botany and Kew Garden Miscellany 1: 235, 1849.

Specimens Examined. India, Uttarakhand: Nainital, Bheemtal, on stump of Quercus leucotrichophora, Sanyal 6905 (PUN), July 24, 2010; Tehri Garhwal, Jaunpur, on stump of Quercus leucotrichophora, Sanyal 6906 (PUN), October 10, 2012.

Remarks. Steccherinum ciliolatum is characterized by being subcylindrical to subfusiform, richly encrusted skeletocystidia, and ellipsoid basidiospores. It has earlier been reported from India by Rattan [4] from Himachal Pradesh, Lalji [5] from district Nainital (Uttarakhand), Sharma [8] from district Chamoli (Uttarakhand) and Himachal Pradesh and listed by Prasher and Ashok [9] from Himachal Pradesh, Ranadive [11] from unspecified localities of India, and Dhingra et al. [12] from Himachal Pradesh. Here we record it for the first time from district Tehri Garhwal (Uttarakhand).

3.4. Steccherinum cremeoalbum. Stecherinum cremeoalbum Hjortstam, Mycotaxon 19: 507, 1984 (Figures 1(5), 1(6), and 2(24-28)).

Basidiocarp resupinate, effused, adnate, up to $150 \mu \mathrm{m}$ thick in section; hymenial surface odontoid, orange white, pale orange to brownish orange when fresh, orange white to pale orange upon drying; margins thinning, fibrillose to fimbriate to indeterminate, paler to concolorous. Hyphal system dimitic. Generative hyphae up to $4.6 \mu \mathrm{m}$ wide, branched, simple septate, thin- to thick-walled; basal hyphae parallel to substrate, loosely interwoven; subhymenial hyphae densely packed, vertically arranged. Skeletal hyphae up to $5 \mu \mathrm{m}$ wide, thick-walled, rarely branched. Skeletocystidia 49-71 $\times$ $6.8-12.6 \mu \mathrm{m}$, subcylindrical to subfusiform, richly encrusted, encrustation dissolves in $3 \% \mathrm{KOH}$ solution; projecting up to $34 \mu \mathrm{m}$ beyond the hymenium. Basidia 15.6-16.3 $\times 3.8-$ $5 \mu \mathrm{m}$, clavate, somewhat sinuous, 4 -sterigmate, without basal clamp; sterigmata up to $4.4 \mu \mathrm{m}$ long. Basidiospores 3-4.4 $\times 1.2-1.8 \mu \mathrm{m}$, ellipsoid, smooth, thin- to somewhat thickwalled, acyanophilous, inamyloid, with oily contents.

Specimen Examined. India, Dehradun: Mussoorie, on decaying angiospermic stick, Sanyal and Hallenberg 6907 (PUN), August 18, 2010.

Remarks. Steccherinum cremeoalbum is characterized by lacking clamps and having fibrillose to fimbriate margins. It has earlier been reported from Sweden and Denmark by
Hjortstam [21]. Here, it is being described for the first time from India.

3.5. Steccherinum fimbriatum. Steccherinum fimbriatum (Pers.) J. Erikss., Symbolae Botanicae Upsalienses 16 (1): 134, 1958. Odontia fimbriata Pers., Observationes mycologicae 1 : 88, 1796 (Figures 1(7), 1(8), and 2(29-33)).

Basidiocarp resupinate, effused, adnate, up to $400 \mu \mathrm{m}$ thick in section; hymenial surface odontoid with round aculei, grayish orange to brownish orange when fresh, grayish red to brownish upon drying; margins thinning, fibrillose to fimbriate, paler to concolorous. Hyphal system dimitic. Generative hyphae up to $4.3 \mu \mathrm{m}$ wide, branched, septate, clamped, thin-walled; basal hyphae parallel to substrate, loosely interwoven; subhymenial hyphae densely packed, vertically arranged. Skeletal hyphae up to $5 \mu \mathrm{m}$ wide, thickwalled, rarely with simple septa. Skeletocystidia very long, encrusted part $60-85 \times 7.4-12.6 \mu \mathrm{m}$, subcylindrical to subfusiform, apically widened, richly encrusted; projecting up to $52 \mu \mathrm{m}$ out of the hymenium. Basidia $13.8-18 \times 4.4-5 \mu \mathrm{m}$, clavate, 4 -sterigmate, with basal clamp; sterigmata up to $5 \mu \mathrm{m}$ long. Basidiospores 3-4 × 1.6-1.8 $\mu \mathrm{m}$, ellipsoid, smooth, thinwalled, acyanophilous, inamyloid.

Specimen Examined. India, Uttarakhand: Champawat, Budhangarhi, on stump of Alnus nepalensis, Sanyal 6908 (PUN), September 04, 2011.

Remarks. This species differs from S. cremeoalbum by clamped generative hyphae. Rattan [4] and Sharma [8] described it from Himachal Pradesh and Jammu and Kashmir. It has also been listed by Ranadive [11] from unspecified localities of India and Prasher and Ashok [9] and Dhingra et al. [12] from Himachal Pradesh. It is being reported for the first time from Uttarakhnad.

3.6. Steccherinum laeticolor. Steccherinum laeticolor (Berk. \& M. A. Curtis) Banker, Mycologia 4 (6): 316, 1912. - Hydnum laeticolor Berk. \& M. A. Curtis, Grevillea 1 (7): 99, 1873.

Distribution. Himachal Pradesh, Uttarakhand.

Remarks. It has earlier been described from India by Rattan [4] from Himachal Pradesh and by Sharma [8] from district Uttarkashi (Uttarakhand). Later, it has also been listed by Bhosle et al. [6] from Maharashtra, Prasher and Ashok [9] from Himachal Pradesh, Ranadive [11] from unspecified localities of India, and Dhingra et al. [12] from Himachal Pradesh.

3.7. Steccherinum ochraceum. Steccherinum ochraceum (Pers.) Gray, A natural arrangement of British plants 1: 651, 1821. Hydnum ochraceum Pers. ex J. F. Gmel., Systema Naturae 2: 1440, 1792.

Specimen Examined. India, Uttarakhand: Bageshwar, Bhedchulla, on log of Quercus leucotrichophora, Sanyal 6909 (PUN), September 02, 2011. 

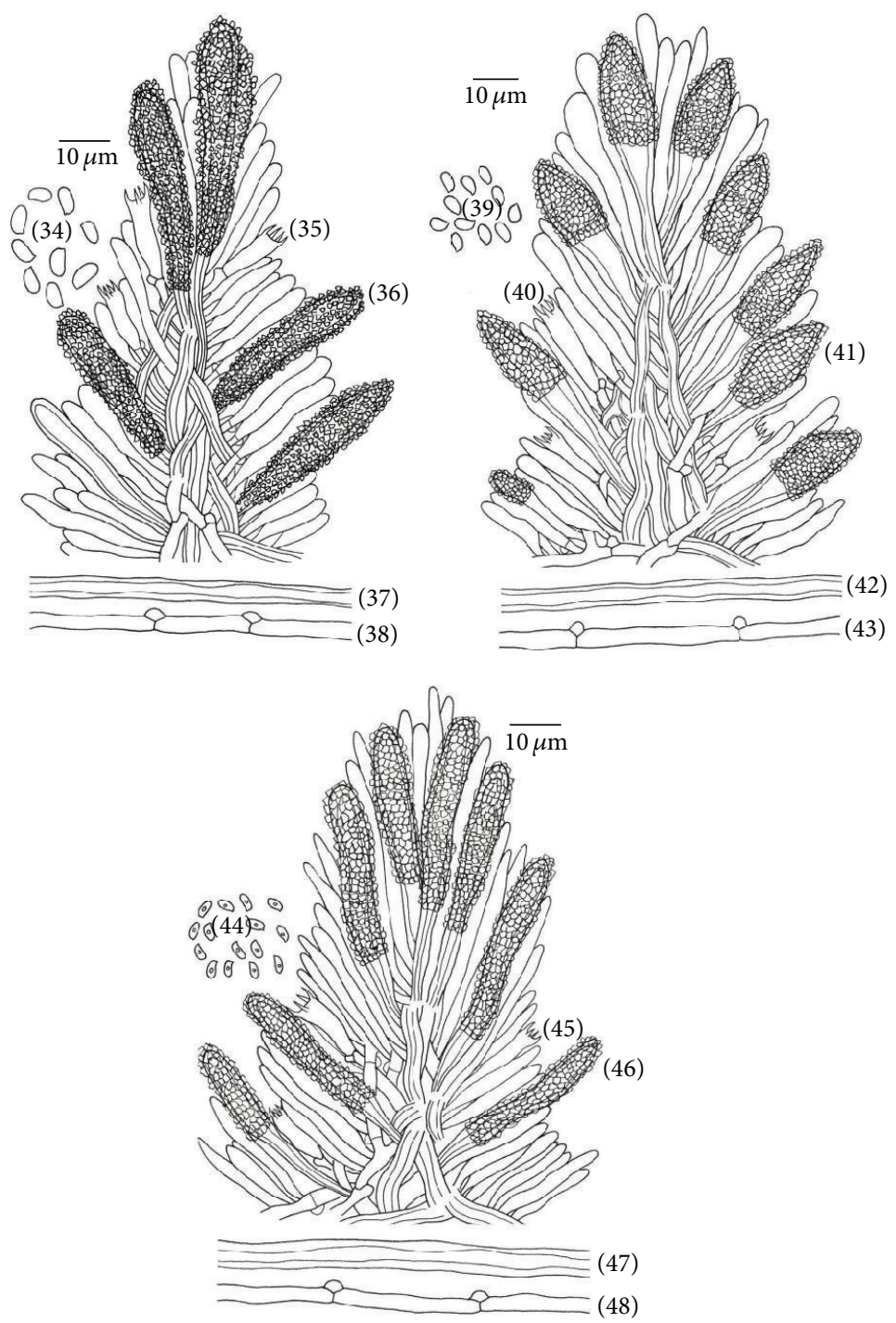

FIGURE 3: Microscopic features of Steccherinum spp.: (34)-(38) Steccherinum oreophilum ((34) basidiospores, (35) basidia, (36) cystidia, (37) skeletal hyphae, and (38) generative hyphae). (39)-(43) Steccherinum robustius ((39) basidiospores, (40) basidia, (41) cystidia, (42) skeletal hyphae, and (43) generative hyphae). (44)-(48) Steccherinum subcrinale ((44) basidiospores, (45) basidia, (46) cystidia, (47) skeletal hyphae, and (48) generative hyphae).

Remarks. The species has earlier been described from India by Thind and Khara [3] from Himachal Pradesh and Uttarakhand, Rattan [4] from H.P., Natrajan and Kolandavelu [22] from Tamil Nadu, Lalji [5] from Uttarakhand, and Sharma [8] from Uttarakhand and Himachal Pradesh and listed by Bhosle et al. [6] as well as Ranadive et al. [7] from Maharashtra, Prasher and Ashok [9] from Himachal Pradesh, Prasher and Lalita [10] from Uttarakhand, Ranadive [11] from unspecified localities of India, and Dhingra et al. [12] from Himachal Pradesh. Here we, report it for the first time from district Bageshwar (Uttarakhand).

3.8. Steccherinum oreophilum. Steccherinum oreophilum Lindsey \& Gilb., Mycologia 69 (1): 193, 1977 (Figures 1(9), $1(10)$, and 3(34-38)).
Basidiocarp resupinate, effused, adnate, up to $1.5 \mathrm{~mm}$ thick in section; hymenial surface aculeate, aculei irregularly flattened, orange white to pale orange to grayish orange when fresh, grayish orange to brownish orange upon drying; margins thinning to indeterminate, paler to concolorous. Hyphal system dimitic. Generative hyphae up to $3.8 \mu \mathrm{m}$ wide, branched, clamped, thin-walled; basal hyphae parallel to substrate, loosely interwoven; subhymenial hyphae densely packed, vertically arranged. Skeletal hyphae up to $4.4 \mu \mathrm{m}$ wide, thick-walled. Skeletocystidia very long, encrusted part $88-125 \times 5.6-7.6 \mu \mathrm{m}$, tubular, apically widened, richly encrusted; projecting up to $67 \mu \mathrm{m}$ beyond the hymenium. Basidia 11.8-17 $\times 4.4-5 \mu \mathrm{m}$, clavate, 4-sterigmate, with basal clamp; sterigmata up to $3.8 \mu \mathrm{m}$ long. Basidiospores 5-6.4 $\times 2.4-3 \mu \mathrm{m}$, ellipsoid, smooth, thin-walled, acyanophilous, inamyloid. 
Specimen Examined. India, Uttarakhand: Dehradun, Devban, on bark of Quercus leucotrichophora, Sanyal 6910 (PUN), September 18, 2012.

Remarks. This species has earlier been described from USA and Europe (http://www.mycobank.org/, 2014). We report it for the first time from India.

3.9. Steccherinum robustius. Steccherinum robustius (J. Erikss. \& S. Lundell) J. Erikss., Symbolae Botanicae Upsalienses 16 (1): 134, 1958. Mycoleptodon robustior J. Erikss. \& S. Lundell, Fungi Exsiccati Suecici Fasc. 43-44: p. 26, 1953 (Figures 1(11), 1(12), and 3(39-43)).

Basidiocarps resupinate, effused, adnate, up to $500 \mu \mathrm{m}$ thick in section; hymenial surface aculeate with conical aculei up to $1 \mathrm{~mm}$ long; pale orange to orange red when fresh, orange white to grayish orange to brownish orange upon drying; margins thinning to indeterminate, paler to concolorous. Hyphal system dimitic. Generative hyphae up to $3 \mu \mathrm{m}$ wide, branched, septate, clamped, thin-walled; basal hyphae parallel to substrate, loosely interwoven; subhymenial hyphae densely packed, vertically arranged. Skeletal hyphae up to $5 \mu \mathrm{m}$ wide, thick-walled. Skeletocystidia very long, encrusted in the apical region; projecting up to $31 \mu \mathrm{m}$ beyond the hymenium. Basidia 13.8-18 $\times 4.4-5 \mu \mathrm{m}$, clavate, 4 -sterigmate, with a basal clamp; sterigmata up to $5 \mu \mathrm{m}$ long. Basidiospores 3-4.4 $\times 2.6-3 \mu \mathrm{m}$, ellipsoid, smooth, thinwalled, acyanophilous, inamyloid.

Specimens Examined. India, Uttarakhand: Udham Singh Nagar, on angiospermous stick, Sanyal 6911 (PUN), September 10, 2011; Udham Singh Nagar, on angiospermous stick, Sanyal 6912 (PUN), September 10, 2011.

Remarks. This species is characterized by very long, apically encrusted cystidia and broadly ellipsoid basidiospores. It has earlier been reported from Bulgaria, the Caucasus, Denmark, Estonia, France, Germany, Italy, Russia, Slovenia, Spain, Sweden, and Ukraine and is here described for the first time from India.

3.10. Steccherinum subcrinale. Steccherinum subcrinale (Peck) Ryvarden, Norwegian Journal of Botany 25: 294, 1978. Hydnum subcrinale Peck, Bulletin of the New York State Museum 167: 27, 1913 (Figures 1(13), 1(14), and 3(44-48)).

Basidiocarp resupinate, effused, adnate, up to $0.5 \mathrm{~mm}$ thick in section; hymenial surface odontoid with conical aculei, grayish orange to brownish orange when fresh, brownish orange to light brown upon drying; margins thinning, sometimes reflexed, fibrillose, whitish to orange white. Hyphal system dimitic. Generative hyphae up to $3 \mu \mathrm{m}$ wide, branched, septate, clamped, thin-walled; basal hyphae parallel to substrate, loosely interwoven; subhymenial hyphae densely packed, vertically arranged. Skeletal hyphae up to $3.8 \mu \mathrm{m}$ wide, thick-walled. Skeletocystidia very long, encrusted part up to $34.4-53 \times 6.2-9.4 \mu \mathrm{m}$, cylindrical to tubular, richly encrusted, thick-walled; projecting up to $39 \mu \mathrm{m}$ beyond the hymenium. Basidia 11.4-13.8 $\times$ $3.8-5 \mu \mathrm{m}$, clavate, 4 -sterigmate, with a basal clamp; sterigmata up to $2.6 \mu \mathrm{m}$ long. Basidiospores 3-3.8 $\times 1.4-1.8 \mu \mathrm{m}$, narrowly ellipsoid, smooth, thin-walled, generally uniguttulate, acyanophilous, inamyloid.

Specimen Examined. India, Uttarakhand: Dehradun, Devban, on bark of Cedrus deodara, Sanyal 6913 (PUN), September 18, 2012.

Remarks. Steccherinum subcrinale is characterized by having narrowly ellipsoid, generally uniguttulate basidiospores. It has earlier been reported from India by Lalji [5] from Punjab. It is here reported for the first time from Uttarakhand.

\section{Conflict of Interests}

The authors declare that there is no conflict of interests regarding the publication of this paper.

\section{Acknowledgments}

The authors thank Head of Department of Botany, Punjabi University, Patiala, for providing research facilities and Professor Nils Hallenberg (Sweden) for his expertise and comments.

\section{References}

[1] M. Binder, D. S. Hibbett, K.-H. Larsson, E. Larsson, E. Langer, and G. Langer, "The phylogenetic distribution of resupinate forms across the major clades of mushroom-forming fungi (homobasidiomycetes)," Systematics and Biodiversity, vol. 3, no. 2, pp. 113-157, 2005.

[2] M. Binder, A. Justo, R. Riley et al., "Phylogenetic and phylogenomic overview of the Polyporales," Mycologia, vol. 105, no. 6, pp. 1350-1373, 2013.

[3] K. S. Thind and H. S. Khara, "The hydnaceae of North Western Himalayas," Bulletin of the Indian Phytopathological Society, vol. 4, pp. 25-33, 1968.

[4] S. S. Rattan, The Resupinate Aphyllophorales of the North Western Himalayas, Bibliotheca Mycologica, Cramer, Berlin, Germany, 1977.

[5] K. Lalji, Mycoflora associated with multipurpose tree species of North-West India [Ph.D. thesis], Punjabi University, Patiala, India, 2003.

[6] S. R. Bhosle, P. Y. Lamrood, and J. G. Vaidya, "Diversity of aphyllophoraceous fungi from the Western Ghats of Maharashtra," in The Fungi-Diversity and Conservation in India, J. S. Dargan, N. S. Atri, and G. S. Dhingra, Eds., pp. 103-113, Bishen Singh Mahendra Pal Singh, Dehradun, India, 2005.

[7] K. R. Ranadive, J. G. Vaidya, P. K. Jite et al., "Checklist of Aphyllophorales from the Western Ghats of Maharashtra State," Mycosphere, vol. 2, no. 2, pp. 91-113, 2011.

[8] J. R. Sharma, Aphyllophorales of Himalaya, Botanical Survey of India, Kolkata, India, 2012.

[9] I. B. Prasher and D. Ashok, "A checklist of wood rotting fungi (non-gilled Agaricomycotina) of Himachal Pradesh," Journal on New Biological Reports, vol. 2, no. 2, pp. 71-98, 2013.

[10] I. B. Prasher and Lalita, "A checklist of wood rotting fungi (non-gilled Agaricomycotina) of Uttarakhand," Journal on New Biological Reports, vol. 2, no. 2, pp. 108-123, 2013. 
[11] K. R. Ranadive, "An overview of Aphyllophorales (wood rotting fungi) from India," International Journal of Current Microbiology and Applied Sciences, vol. 2, no. 12, pp. 112-139, 2013.

[12] G. S. Dhingra, A. P. Singh, J. Kaur et al., "A checklist of resupinate, non-poroid Agaricomycetous fungi from Himachal Pradesh, India," Synopsis Fungorum, vol. 32, pp. 8-37, 2014.

[13] A. Kornerup and J. H. Wanscher, Metheun's Handbook of Colours, Metheun and Co., London, UK, 3rd edition, 1978.

[14] M. Blackwell, D. S. Hibbett, J. W. Taylor, and J. W. Spatafora, "Research Coordination Networks: a phylogeny for kingdom Fungi (Deep Hypha)," Mycologia, vol. 98, no. 6, pp. 829-837, 2006.

[15] T. Y. James, F. Kauff, C. L. Schoch et al., "Reconstructing the early evolution of Fungi using a six-gene phylogeny," Nature, vol. 443, no. 7113, pp. 818-822, 2006.

[16] D. S. Hibbett, M. Binder, J. F. Bischoff et al., "A higher-level phylogenetic classification of the Fungi," Mycological Research, vol. 111, no. 5, pp. 509-547, 2007.

[17] P. M. Kirk, P. F. Cannon, D. W. Minter, and J. A. Stalpers, Dictionary of the Fungi, CABI Publishing, Wallingford, UK, 10th edition, 2008.

[18] A. Bernicchia and S. P. Gorjón, Corticiaceae s.l. Fungi Europaei 12, Edizioni Candusso, Alassio, Italy, 2010.

[19] K. Hjortstam and L. Ryvarden, "Some new and noteworthy Basidiomycetes (Aphyllophorales) from Nepal," Mycotaxon, vol. 20, no. 1, pp. 133-151, 1984.

[20] N. Hallenberg and K. Hjortstam, "Studies in Corticiaceae (Basidiomycetes) new species and new combinations," Mycotaxon, vol. 31, no. 2, pp. 439-443, 1988.

[21] K. Hjortstam, "Notes on Corticiaceae (Basidiomycetes). XIII," Mycotaxon, vol. 19, pp. 503-513, 1984.

[22] K. Natrajan and K. Kolandavelu, Resupinate Aphyllophorales of Tamil Nadu, India, India Centre for Advanced Study in Botany, University of Madras, Chennai, India, 1998. 

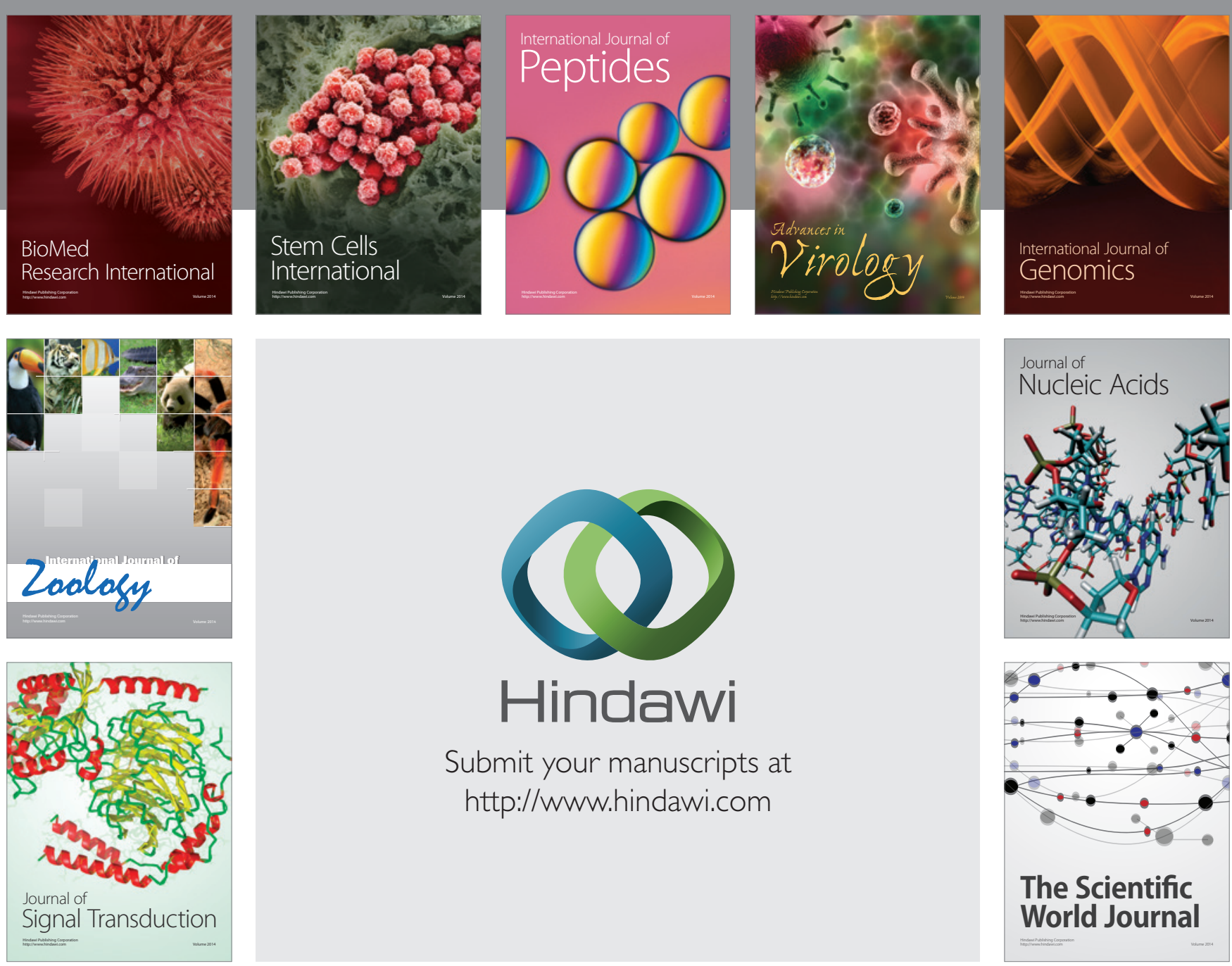

Submit your manuscripts at

http://www.hindawi.com
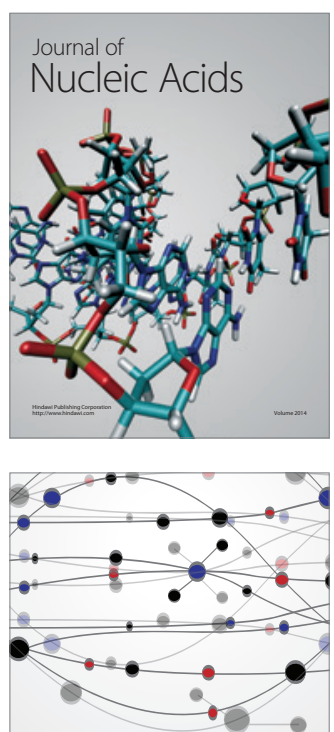

The Scientific World Journal
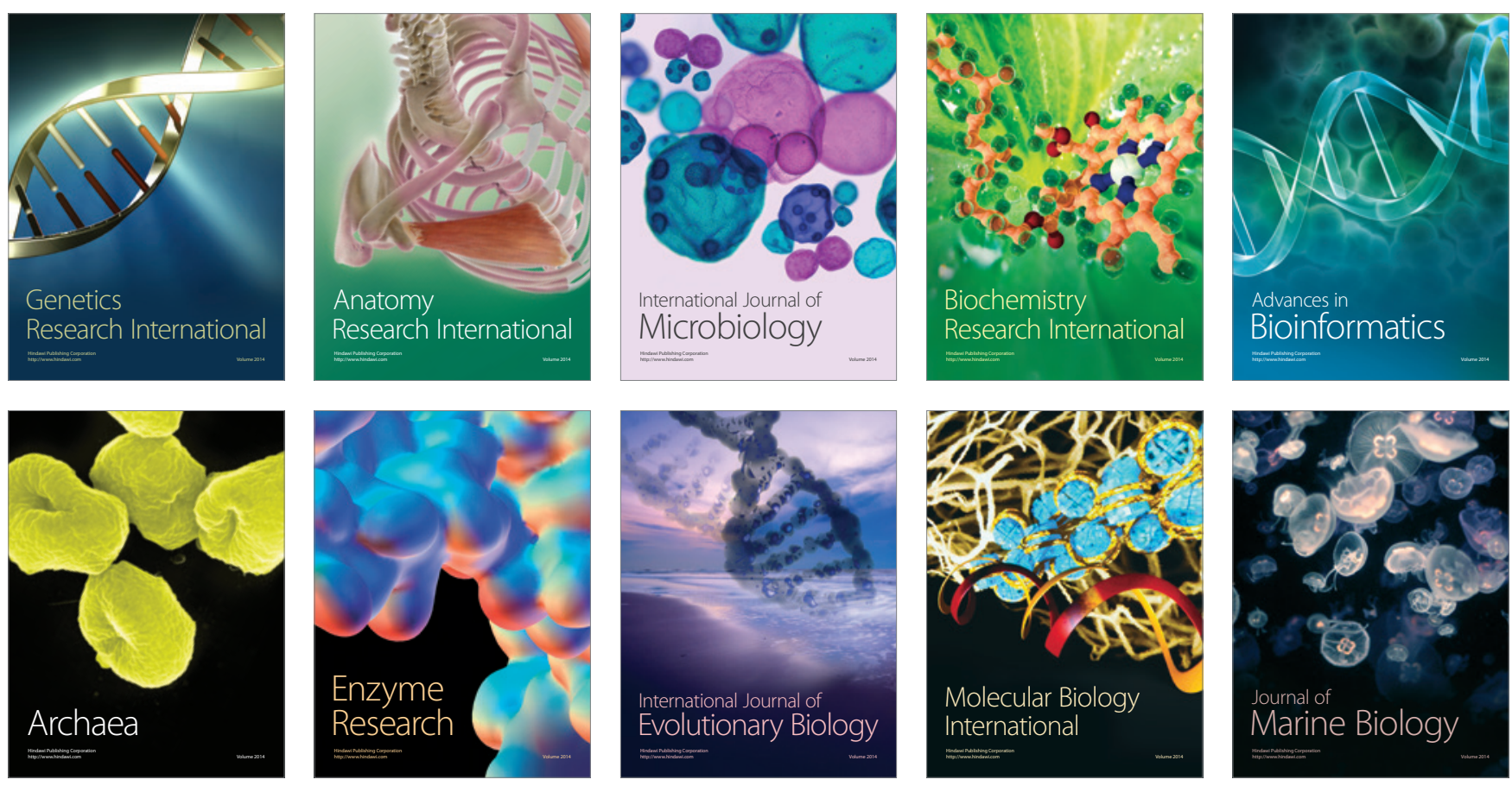